Article

\title{
Between Sustainable and Temporary Competitive Advantages in the Unstable Business Environment
}

\author{
Letycja Sołoducho-Pelc ${ }^{1, *}$ and Adam Sulich ${ }^{2, *}$ (i) \\ 1 Strategic Management Department, Wroclaw University of Economics and Business, \\ 53-345 Wroclaw, Poland \\ 2 Department of Strategy and Management Methods, Wroclaw University of Economics and Business, \\ 53-345 Wroclaw, Poland \\ * Correspondence: letycja.soloducho-pelc@ue.wroc.pl (L.S.-P.); adam.sulich@ue.wroc.pl (A.S.)
}

Received: 30 September 2020; Accepted: 22 October 2020; Published: 24 October 2020 check for
updates

\begin{abstract}
Gaining a competitive advantage assumes that a company should build a unique position, but this concept is related to a relatively stable environment. However, it is difficult to predict the consequences of the enterprises' changes, leading to changes both in the business and natural environment. Therefore, this study's authors asked a research question: Is it possible to restore a balance between durability and variability of the organization in terms of strategy? The answer to such a question was drawn upon the literature review and survey research. This paper presents a qualitative and quantitative model of competitive advantage in a changing business environment. This article uses an inductive inference method supported by a literature study and a deduction method supported by statistical calculations, based on a survey conducted among 150 Polish companies in different economic sectors. As a result of the research methods, a dualistic competitive advantage model in a changing environment was proposed and discussed. The article's aim was achieved in the model combining a sustainable (SCA) and temporary competitive advantage (TCA). Understanding the conditions for gaining competitive advantage allowed to formulate general conditions under which sustainable strategic management can be built to consider sustainability objectives and contribute to the green economy. This research has confirmed that building a competitive advantage in unstable conditions requires finding a balance between implementing the planned development strategy and using new opportunities.
\end{abstract}

Keywords: ecological strategy; green management; sustainable development; strategic management

\section{Introduction}

Modern organizations face more difficult challenges, characterized by novelty, broad reach, and extreme volatility due to business [1] and natural environment [2]. These complex challenges highlight the importance and synergies of the economic, social, and environmental processes [3] underlying the organization's strategic efforts to gain a competitive advantage [4]. They are visible on a global scale and impact social and economic development [5]. Moreover, environmental problems contribute to economic and financial crises, which entail social issues [6-8]. Businesses are rarely giving anything positive in return to the natural environment, which is the basis for their resources [9]. It is crucial to examine the mechanisms for companies' strategies, which have to consider the natural environment impact, especially when gaining a competitive advantage is a choice between stable (sustainable) and unstable (temporary) strategies.

Strategic management treats business environment variability as a critical determinant of strategy development $[10,11]$ and this means implementing the strategy by continually seeking the possibility of adapting the organization to changing external and internal conditions [12]. The critical strategic 
management assumptions are related to long-term management [13,14] and active future creation of organizations, and then include [15]: (1) focus on the life-long development of the organization; (2) decisions analysis for their long-term effects; (3) scheduled change management; (4) innovation and the development of future solutions. A setting in the direction of development means that the company's actions are not accidental, although they are based on a balance between volatility and stability [16]. A studied and consistently implemented strategy should ensure the organization's longevity and uniqueness concerning competition [17] in the business environment. The strategic management environmental dimension related to the sustainability concept is a new research subject $[3,17,18]$.

In this article, we noted that a dynamic but sustainable strategy is created due to the balance between temporality and stability. This type of strategy can be accompanied by sustainable strategic management, which considers environmental aspects [17]. Considerations between rigidity (stability) and flexibility (temporality) relate primarily to anticipating the organization's future operating conditions. Then, it is difficult for many organizations to reconcile the contradiction between the planning of the action (stable long-term perspective) and the flexibility of their strategy [5]. On the one hand, organizations should respond fast enough to changes. On the other, organizations seek to exploit future opportunities in the process of long-term, sustainable, and stable development $[5,19]$. It is essential to anticipate the future conditions and effects of planned actions, especially those relating to ecology and the natural environment, and to include them in the strategies. These factors can decide about the strategy type choice.

This research aims to discuss a competitive advantage in a changing business environment and present the relationship between sustainable (SCA) and temporary competitive advantage (TCA). This aim was accomplished in qualitative and quantitative models of competitive advantage based on research in a real business environment. Presented on figures, qualitative model is a result of a literature review. The quantitative model is then based on the data obtained in a survey among a randomized sample of 150 Polish companies in various economic sectors noted in the Warsaw Stock Exchange. Presented models explain the relations between TCA and SCA.

The temporary (TCA) and sustainable competitive advantage (SCA) presented in the scientific literature relates to a narrow research area. Researchers rarely issue the relationship between a TCA and SCA and focus more on choosing one of the strategy types. The paradigm has been assumed in the literature that a sustainable and temporary competitive advantage are alternatives to each other (exclude each other) [19-21]. Besides that, sustainability can have another dimension strictly related to ecology and environmental problems [6]. In this paper, we acknowledge that there is a difference between the idea of sustainability in strategic management sciences and environmental sciences.

There is a research gap in terms of competitive advantage, which concerns researchers and business practitioners' views on the strategy choice problem. Firstly, the development of knowledge about competitive advantage has not kept pace with the organization's changing needs and the business environment [20,22-25]. Secondly, there is a lack of competitive advantage research under new operating conditions caused by strive to achieve stability $[10,26,27]$. There is a need for statistical methods to clarify the mechanism for formulating the strategy [28]. Finally, it is required to update theoretical models and propose new better-suited models to modern realities. In this context, there is a need for research about the organization's factors in building a competitive advantage in a changing business environment, taking into account the environment when strategy choice is made [18]. This research gap in synergies between TCA and SCA allowed us to propose a new model.

In our research, we assumed that sustainable and temporary benefits are not mutually exclusive. Sustainable (SCA) and temporary competitive advantages (TCA) can coexist in the organization and shape each other. They can build a dynamic equilibrium in a choice between TCA and SCA [19-21]. This approach allowed us to develop a competitive advantage gaining model in a changing environment, considering environmental factors (which influence innovations and new market standards). The optimal solution for organizations operating in a changing environment is to have sustainable (SCA) and temporary competitive advantage (TCA). This combination helps an 
organization to build competitive advantages and to combine dynamics and durability. Proposing an inclusive direction of research on SCA and TCA sets a new analysis approach that incorporates sustainable development. In the summary of this research, we proposed a unique competitive advantage model in a changing business environment. We also presented some final remarks and limitations related to conducted research with possible further research perspectives.

\section{Theoretical Background}

Researchers present many definitions of competitive advantage in scientific literature related to strategic management [29]. Researchers point to a differentiation between long-term SCA and TCA [26]. Other terms for the systematization and characteristic of competitive advantage strategies are also proposed, introducing the concept of stable competitive advantage, or durable and occasional competitive advantage or temporary one $[8,30]$.

In most competitive advantage definitions, more attention is paid primarily to competitors, customers, and the company [25]. The position of competitors and their strategy provide a benchmark for assessing competitive advantage. Therefore, it is essential to gain a dominant position in the market and keep a distance from competitors [20]. In the classic definition, Porter describes competitive advantage as the ability to achieve better results than competitors in the industry or the same market [8]. In his explanation, an advantage is related to the company's exceptional value to customers [14]. This extraordinary value is due to lower prices and extraordinary benefits for the customer [31].

On the other hand, Barney equates a competitive advantage with long-term benefits through the implementation of a value-creating strategy [14]. According to him, the company's strategy should be exceptional, as the resulting advantages cannot be replicated by competitors [32]. However, Peteraf defines competitive advantage as an organization's ability to maintain above-average profits [33]. Grant pointed out that a competitive advantage allows for a higher profit rate than its competitors, sustainably [34]. Peteraf and Barney have agreed that companies with a competitive advantage generate higher economic value [35]. From an economic perspective, competitive advantage studies often highlight the improved efficiency of organizations. In strategic management, profit, market share, and value creation are crucial [16,36]. Both Porter [31] and Grant [34] pay attention to getting better results than competitors, translating into a higher profit rate when defining competitive advantage. What is more, Barney combines a competitive advantage to achieve the undertaking's primary objective of creating value. However, all researchers agree that the organization's unique position can be an effect of various perspectives and variables, and these are both endogenous and exogenous (external) factors.

According to the Industrial Organization Theory [31], the advantage is shaped by exogenous forces, resulting from the industry's market position (the so-called industry effect). When environmental factors change, the competitive advantage gained from the business environment's structure can change [31]. According to Porter, the competitive advantage should be permanent, timeless, and unique [37]. Such an advantage is difficult to copy, even in the long term [38]. The TCA allows for constant, high profitability and builds value. In this way, the organization can stand out from competitors and gain loyal customers [8]. The concept is under criticism for limiting the analysis of advantages to the industry. A change in natural environmental factors can result in the loss of sustainable advantage [20]. It weakens the original competitive advantage resulting from the existing market structure and organization flexible TCA [39].

On the other hand, there are competitive advantage studies related to endogenous factors. Such an approach is characteristic of the Resource-Based View (further abbreviated in this article as RBV), which considers resources and used opportunities to shape competitive advantage [40]. The RBV points to strategic resources as an essential source of competitive advantage [41]. The RBV researchers and representatives believe that the organization's profits are in the long term; more important (than the impact of the industry) are unique resources, position, and strategy [42]. The primary representative of this RBV-based concept is Barney [43]. According to him, the condition for achieving SCA is to have unique resources that are: rare, unique, and valuable. Resources are essential for developing 
organizations and maintaining a competitive position in the market [44]. In theory, RBV draws attention to the need to acquire and develop resources, transform them continuously, and use them in innovative processes to create new products and services. Then, an organization should pursue such a strategy because of the threat from competition. Building a competitive strategy based on exceptional resources [45] requires a lot of money to acquire resources and use them effectively [7]. The solution for such a problem is incorporating sustainable development (ecological) principles in the whole organization strategy. In this paper, we refer to the RBV school, and we emphasize the importance of not so many resources, but exceptional capacities determining the use of resources [46]. In their research, Eisenhardt and Martin refer to organizations' dynamic capabilities that can provide a competitive advantage in a turbulent business environment [30]. These researchers defined dynamic capabilities as processes $[47,48]$, where the organization's resources can adapt to or even create market changes [30]. The management literature has not been studied for whether dynamic capabilities contribute to building lasting benefits or a sequence of temporary benefits.

Temporary competitive advantage (TCA) is becoming increasingly important in research due to the need to respond to the speed and unpredictability of changes [3]. The concept of dynamic capabilities refers to organizations' characteristics, routine behavior that allows changes to adapt quickly and accurately $[8,20,38,39]$. The researchers assume that companies have several sources of short-term advantage. Then, TCA is developed, until changes in the business environment cause it to become too large and long-term related [24]. Changing the short-term advantage requires a change in the company's strategy [26]. TCA is part of a strategy that is dynamic and changing [49]. Flexibility and speed of actions play an important role in building TCA [50]. Companies gain the opportunity not only to adapt to changes but also to create them [49]. TCA is often associated with the creation of new solutions, experimenting, and discovering to attract customers' attention [51].

Further conditions of the evolving environment are changing how companies operate [27]. Enterprises are moving away from traditional solutions towards creating new ideas as a result of new technologies [29], such as creating a proper interpretation of signals indicating the changes, an adequate response of the company, and reaction pace [52]. It is a risky and challenging task because one should strive for adaptive perfection [53] in many areas simultaneously [54]. Stieglitz, Knudsen, and Becker, in their research, consider whether strategic flexibility is an appropriate way to obtain temporary benefits. Strategic flexibility involves taking advantage of business opportunities, investing in adaptability, and unplanned use of resources [55]. This approach gives the organization a TCA, despite operating in an uncertain, volatile market.

Doubts raised in the literature concern the possibility of maintaining a TCA as in the strategy. There is also a tendency to shorten the time horizon for planning operational activities [56]. The TCA (dynamic) in some researchers' assessment seems to be better suited to business environment variability (the change towards a green economy is then an element of this environment). Both practitioners and theoreticians assume today that it is possible to compete effectively by building a TCA, which is the source of quick wins [57].

Sustainability studies of competitive advantage highlight an increase in temporary benefits, a reduction in the competitive advantage duration, and a less frequent existence of a SCA [57]. Researchers also point to a series of temporary benefits replacing lasting benefits [41]. Studies focus on factors that researchers believe to affect most of the SCA (Figure 1). Among the considered factors leading to SCA are people, resources, strategic capabilities, strategy, culture, technology and innovation, industry outcomes, innovation, and dynamic capabilities [36]. Selected factors are presented in Figure 1. 


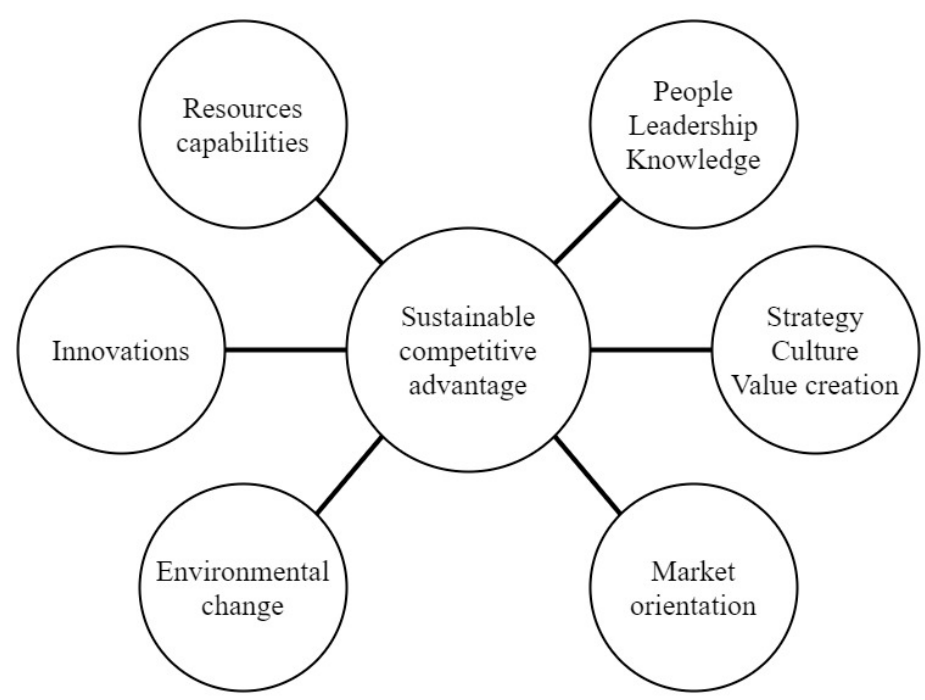

Figure 1. Selected factors shaping SCA (sustainable competitive advantage). Source: Authors' elaboration.

According to strategic management researchers, maintaining a competitive advantage based on resources is very difficult in a dynamic environment. Resources can be easily copied, quickly "age", lose value from the customer's point of view, and their diffusion in the industry is fast [44]. It is not just a transition in the environment that can trigger resource changes. The life cycles of organizations, products, and services cause products to change [58]. It also seems increasingly challenging to build a competitive advantage based on core competencies [2]. This approach emphasizes resource use, as owning them alone does not bring benefits [59]. As an answer to this dilemma, proposed in the many research pieces is SCA, which requires using resources and opportunities arising primarily from technology [60]. Resources and their utilities influence the outcome of a SCA [61].

In the management literature, there is an increased interest in organizations' survival in a dynamic business environment. The new operating conditions force adaptation, so learning becomes the primary mechanism for dealing with change. González-Rodríguez and Díaz-Fernández have highlighted the growing interest of the organization in achieving SCA [62]. Guimaraes et al. studied SCA and organizational performance. It is crucial to pay attention to environmental sustainability and social responsibility as SCA attributes [10]. Hoffman took stock of the research on SCA and examined the development of this concept, its sources, and the relationship between SCA and strategy concepts, and finally, its importance. According to Hoffman, a SCA underpins the company's long-term success and must be seen from an external perspective as unique to competitors [63]. Sirmon, with his research team, highlighted the importance of SCA in strategic management [64]. Their study focused on the direct and integrated impact of capability strengths and weaknesses on competitive advantage and its empirical correlate-relative performance. Changes in environmental factors and their implications for a competitive advantage over time have also been the subject of research [24].

In this age of change, some researchers ask a question: What would the field of strategic management look like if SCA did not exist? [23]. D'Aveni et al. pointed out that the importance of the temporary component of competitive advantage increases to the long-term element [47,48]. Researchers wondered whether the organization's flexibility and the use of variable, short-term opportunities could provide a long-term competitive advantage (SCA). O'Shannassy researched to understand the SCA and TCA, and studied the relationship between environmental uncertainty, material resources, and competitive advantage. The nature of the environment and industry contributes to achieving a competitive advantage. In some industries, organizations can only gain TCA [22]. Huang, with coauthors, pointed to the relationship between TCA and SCA [20]. The researchers highlighted difficulties in defining and distinguishing between two different strategy types. They looked at the dilemma and how to convert a TCA into a SCA. According to their findings, a strong market 
position allows for a strong TCA. To turn the result of TCA into SCA, the researchers proposed several postulates: 1 ) focus on resources enables organizations to achieve SCA; 2) TCA improves access to resources and its use; 3 ) it has a positive impact on SCA, which can be achieved through a series of TCA; 4) organizations can use TCA to improve technological capabilities, which can ultimately help build SCA [20]. Companies with a high resource or technical potential can gain a better result in SCA. Using resources and capabilities (Resource-Based View), we propose to study the transformation of TCA into SCA. A better TCA result from a strong market position (Industrial Organization Theory) converts TCA's value to resources and capabilities. It is worth noting that world stability's assumption plays a vital role in the proposed, so far, in the literature concepts. In their research, Wiggins and Ruefli assumed that companies that have achieved several temporary advantages over some time have a SCA [57]. According to the researchers, dynamic capabilities are essential for development in active markets [47,65]. The dynamic capabilities and flexibility of the organization are identified as a source of TCA [36]. Researchers [46] also proposed the concept of a dynamic capabilities perspective to respond to changes in the environment and new opportunities for value creation, which opened a perspective for SCA research [36].

As we presented in this part of the article, forces that shape TCA are far less likely to be investigated. The study of the relationship between a SCA and a TCA is a poorly recognized research area. Therefore, we decided to present our research methods and results to propose them in the proposed dualistic competitive advantage model in a changing business environment.

\section{Materials and Methods}

The research is based on a randomized sample of 150 Polish companies $(\mathrm{N}=150)$. The respondents were public joint-stock companies listed on the Warsaw Stock Exchange (WSE). The survey involved only companies that were founded based on the Polish capital. There were no more conditions for the sample choice. We surveyed companies' chief representatives anonymously. In this research paper, we present only a fraction of the obtained results.

The calculations were performed in Statistica@by the StatSoft Poland ${ }^{\mathrm{TM}}$. The detailed method explanation in this article is accompanied further with the obtained calculations and results presentation.

The subject of the research concerned the practice of strategic management in enterprises. The questions in the fundamental part concerned three areas: the form and content of the strategy, the process of strategic management, and participants in strategic management. This article presents the research results on competitive advantage related to the interview questionnaire (questions P30, P31, P32, P34, respectively).

\section{Results}

This paper has researched the randomized sample of the general population consisting of Polish companies listed on the Polish Stock Exchange $(\mathrm{N}=150)$. We defined the two sets of variables based on the survey questions, as presented in Table 1 . They examined five variables divided to create: the first set of dependent variables (P30, P31, and P32) and the second set of dependent variables (P33 and P34).

Table 1. Variables and their meanings used in this study.

\begin{tabular}{cr}
\hline Variable Symbol & Variable Statement/Meaning \\
\hline P30 & We have a significant advantage over competitors \\
P31 & To win the customer, we are ready to modify our business profile \\
P32 & The flexibility of operation and speed of reaction are the most critical competitive \\
P33 & advantage of our company \\
P34 & The set new standards in the industry (technological, product, organizational, etc.) \\
\hline
\end{tabular}

Note: Italic format represents the researched statements as variables; Source: Authors' elaboration. 
This paper assumes that the first set of variables is dedicated to the SCA and companies' strategy durability in time. In contrast, the second set of variables describes TCA, so it is related to the quick changes.

We examined the correlation and regression to check the interdependencies between variables and discover the shape of these relations. We claim that the correlation examination between variables has a sense, only if there is a cause and effect relationship, which can be logically explained. In this paper, we have proved by calculations in the Statisticaßsoftware by StatSoft Poland programming environment that independent variables are not correlated to each other. Dependent variables are strongly correlated, as presented in Table 2 . All presented values are statistically significant in all tables and calculations' results in this paper.

Table 2. Correlation matrix.

\begin{tabular}{ccccccc}
\hline Variable & P30 & P31 & P32 & P33 & P33 & P30 \\
\hline P30 & 1.000000 & 0.220206 & 0.167989 & 0.312730 & 0.285073 & 1.000000 \\
P31 & 0.220206 & 1.000000 & 0.429698 & 0.264418 & 0.371549 & 0.220206 \\
P32 & 0.167989 & 0.429698 & 1.000000 & 0.401487 & 0.376551 & 0.167989 \\
P33 & 0.312730 & 0.264418 & 0.401487 & 1.000000 & 0.677373 & 0.312730 \\
P34 & 0.285073 & 0.371549 & 0.376551 & 0.677373 & 1.000000 & 0.285073 \\
\hline
\end{tabular}

Source: Authors' calculations.

The obtained results prove the correct division of variables into two sets and their interdependencies measured by the Pearson correlation. We checked the relations between variables by the covariance and their arithmetic average, as presented in Table 3.

Table 3. Average values and standard deviations.

\begin{tabular}{cccc}
\hline Variable & Average Value & Std. Dev. & Important Cases No. \\
\hline P30 & 3.833333 & 1.200764 & 150 \\
P31 & 3.386667 & 1.257390 & 150 \\
P32 & 3.393333 & 1.192238 & 150 \\
P33 & 3.500000 & 1.413027 & 150 \\
P34 & 3.680000 & 1.142939 & 150 \\
\hline
\end{tabular}

Source: Authors' calculations.

Based on the calculations, we proved that all cases are essential to building a linear model in the regression procedure (Table 3). We decided to calculate a model to describe dependencies between two sets of variables. In the results of calculations, we discovered that only one of the dependent variables-P34, is characterized by the independent variables P33 and P30 with greater relevance, respectively. The results of the backward step regression based on all $\mathrm{N}=150$ cases are presented in Table 4.

Table 4. Dependent variable P34 regression summary.

\begin{tabular}{ccccccc}
\hline $\mathbf{N}=\mathbf{1 5 0}$ & \multirow{2}{*}{$\mathbf{b}^{*}$} & $\begin{array}{c}\text { Std. Err. } \\
\mathbf{b}^{*}\end{array}$ & $\mathbf{b}$ & $\begin{array}{c}\text { Std. Err. } \\
\mathbf{b}\end{array}$ & $\mathbf{t}$ (147) & $\boldsymbol{p}$ \\
\hline Intercept & & & 0.865060 & 0.419480 & 2.062219 & 0.040947 \\
P33 & 0.359086 & 0.073746 & 0.422562 & 0.086782 & 4.869216 & 0.000003 \\
P30 & 0.252408 & 0.073746 & 0.299151 & 0.087403 & 3.422664 & 0.000803 \\
\hline
\end{tabular}

Note: Model characteristics: $\mathrm{R}=0.87233874 ; \mathrm{R}^{2}=0.86310389$; Corr. $\mathrm{R}^{2}=0,87253387 ; \mathrm{F}(2.147)=21.107 ; p<0.000001$; Error std. estimation: 1.2539; symbols meaning: $\mathrm{b}^{*}$ - standardized coefficients, $\mathrm{b}$-directional coefficients of equation; Source: Authors' calculations.

The regression procedure aims to indicate the primary model of the phenomena based on the reduced number of dependent and independent variables. As a result, we have obtained the simplified 
equation, representing the relations between P34 and P30, P33 variables. The linear model formula (linear polynomial) is presented as Equation (1).

$$
\mathrm{P} 34=\mathrm{P} 33 \times 0.422562+\mathrm{P} 30 \times 0.299151+0.865060 \pm 1.2539
$$

In this equation, the variables' meaning is the same as in Table 1.

We have verified the model, which consists of checking the model assumptions:

1. The significance of linear regression;

2. The importance of partial regression coefficients;

3. No collinearity (redundancy) between independent variables;

4. Homoscedasticity assumption, which means that the variance of the random component $(\varepsilon i)$ is the same for all observations;

5. No residual autocorrelation;

6. Normal residual distribution;

7. The random term $\varepsilon_{\mathrm{i}}$ has the expected value equal to 0 .

We verified the obtained model, and we proved that:

1. The linear regression's significance is represented by the values $\mathrm{F}=21, p<0.000001$ which proves that the obtained equation is significant. Additionally, multiple correlation coefficient $R=0.87$ which supports linear dependencies between chosen variables to the model (Equation (1));

2. Calculated $p<0.000001$ value proves the significance of partial regression coefficients, additionally marked in red color in Table 4;

3. There is no collinearity between independent variables. The tolerance for both variables is high, and its value is close to the 1 ;

4. The homoscedasticity assumption is fulfilled and supports the linearity of the model;

5. There is no residual autocorrelation as presented in Table 5;

6. There is also normal residual distribution as illustrated in Figure 2;

7. The random term $\varepsilon_{\mathrm{i}}$ has the expected value equal to 0 because the average value of the Cook's distance equals 0 .

Table 5. Model verification— $\mathrm{d}$ Durbin-Watson value and residual serial correlation.

\begin{tabular}{ccc}
\hline Feature & d Durbin-Watson & Residual Serial Correlation \\
\hline Estim. & 1.803191 & 0.094358 \\
\hline \multicolumn{3}{c}{ Source: Authors' calculations. }
\end{tabular}

The obtained linear model describes chosen variables from the two sets and the regression results, which reduced the number of variables used in the final model to describe statistically significant the relations between P34 and P30, P33 variables. Therefore, we have proved the interchangeable character of these SCA and TCA related variables. In the discussion of the model, we can explain that P30 (We have a significant advantage over competitors) can be understood as a stable state of preparation and declaration of the required assets' possession to gain SCA. More significant for the model is variable P33 (We set new standards in the industry—technological, product, organizational, etc.), which is also a more decisive declaration about current but elaborated in time competitive advantage. We understand this, although this variable measured in the survey also reflects elasticity and TCA. Therefore, we discovered that P33 and P34 are dependent variables strongly correlated to each other (Table 2). However, the variable P34 and measured statement (The primary competitive advantage of our company is based on innovation and technology) represents the most rapid and elastic TCA capacity among all examined companies $(\mathrm{N}=150)$. 


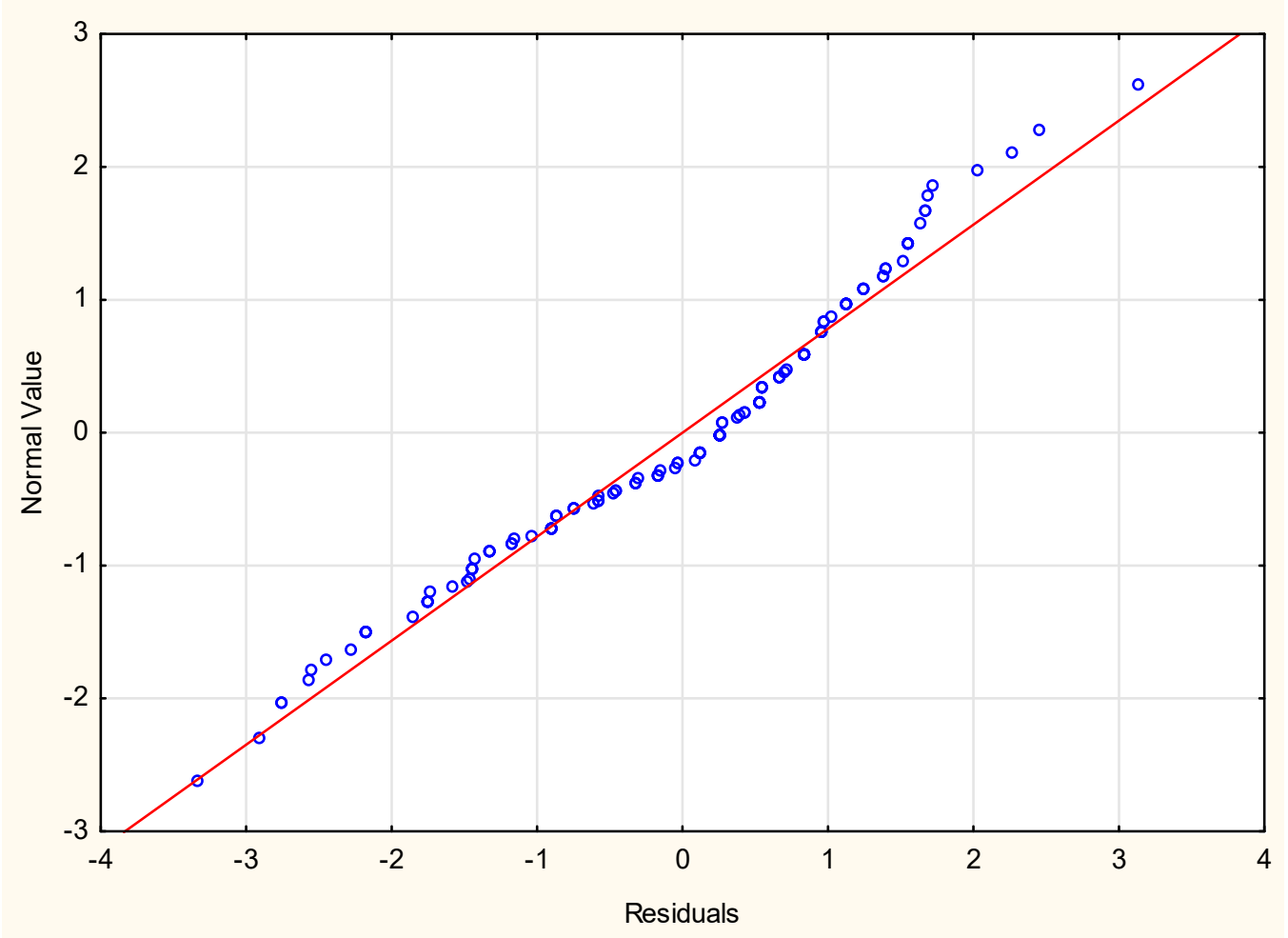

Figure 2. Normality plot of residuals. Source: Authors' calculations.

\section{Discussion}

Based on the presented results section calculations, we proposed an elaborated model that considers variables' interdependencies, as presented in Figure 3. This model is discussed in this section.

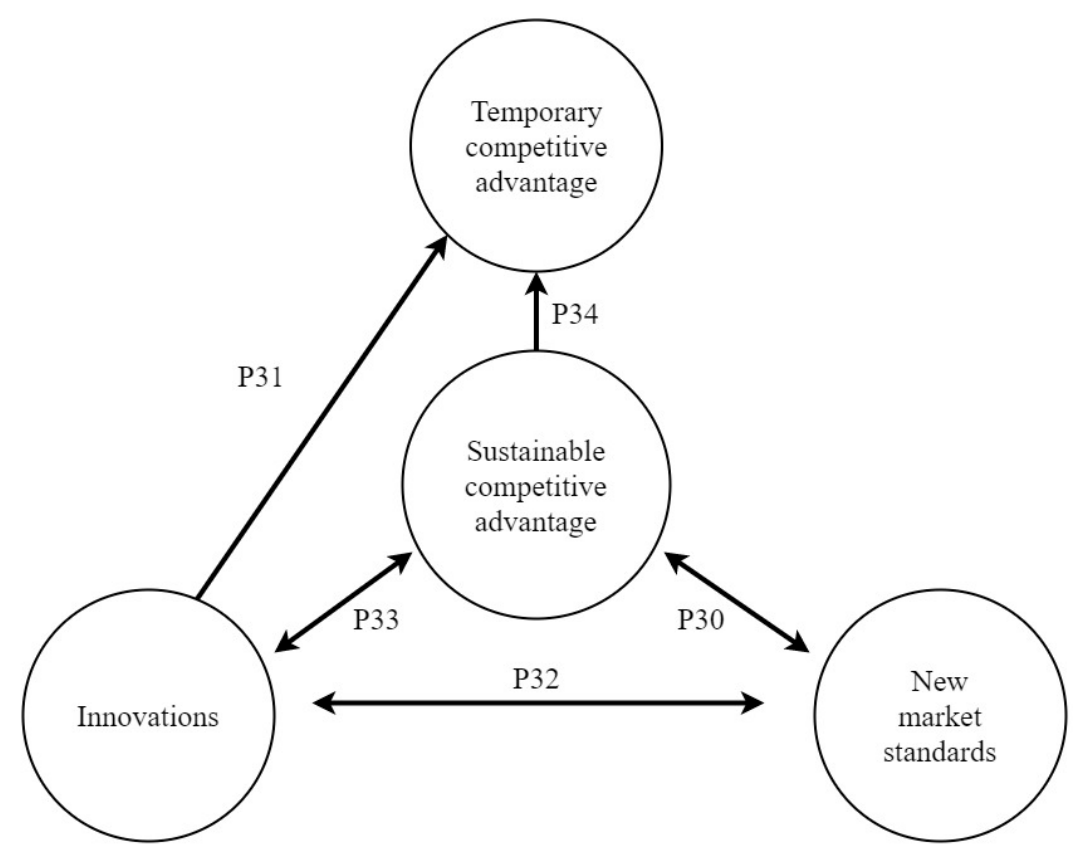

Figure 3. Presentation of research results in the area of SCA and TCA. Source: Authors' elaboration.

Based on the conducted survey results and proposed model (Figure 3), three statements (with these, respondents were asked to agree or disagree) were most important: 
1. P30. We have a significant advantage over our competitors;

2. P33. We set new standards in the industry (technological, product, organizational, etc.);

3. P34. Our company's primary competitive advantage is based on innovation and technology.

As presented in Figure 3, SCA and TCA are related to innovation and technology (P31). On the other hand, the SCA can be recognized as gaining a competitive advantage based on new market standards (P30) related to innovations (P32). SCA shapes both setting new industry (P30) and the TCA based on innovation (P31). There is a strong relation between SCA and a TCA (P34). Obtained results prove that significant competitive advantage over competitors means a long-lasting advantage. Its acquisition requires the implementation of an appropriate development strategy in the long term (SCA). The results of our research prove that SCA is an advantage of strategic importance. Maintaining it positively influences other advantages related to innovation and technology, and sets new standards in the industry. Then, a SCA can be considered an advantage that determines an organization's success in the short and long term.

The relation between SCA and TCA is linear and represents mutual relation as presented in Equation (1) and Figure 3. The advantage of the industry leader, which sets new standards in diverse functional areas, is associated with a competitive advantage based on innovation and technology. Gaining a SCA requires developing design and technology, and setting new standards in the industry. At the same time, a TCA is based on a competitive advantage based on innovation and technology (Figure 3).

To have a SCA and a TCA, which is the optimal solution for organizations operating in the unstable business environment, it is necessary to have an advantage based on innovation and technology, and set new industry standards. Compared to the results of studies by other researchers, our results differ. The study does not deal with an "either-or" choice between a SCA and TCA. The results of our research show that when SCA is formed, it can occur together with TCA.

Referring to the research team's research results, we found that in Huang, Dyerson, $\mathrm{Wu}$, and Harindranath, similarly to our study, SCA determines the TCA [20]. SCA is a core competitive advantage that determines an organization's sustainable development in the short term and long term [66]. D'Aveni, Dagnino and Smith noted the increase in the temporary factor in the competitive advantage and the decreasing importance of the permanent component [19]. O'Shannassy, Madsen and Leiblein found that temporary advantages can be an alternative to SCA [67]. Wiggins and Ruefli suggested that organizations have a sustainable competitive advantage after some time but earlier have to achieve several temporary advantages [57]. Our research proves that a SCA and a TCA develop into each other dynamically what represents a linear equation. It is vital to strive to balance these advantages so that the organization, in response to the environment's volatility, aims at sustainable development (added customer value) in the long term. This, in turn, will allow the organization to react quickly and flexibly to changes.

The literature research process allowed us to develop a theoretical model of gaining a competitive advantage based on TCA and SCA strategies. The model represents a summary of the theoretical and empirical research results, allowing using this concept of the competitive advantage for seizing development opportunities and managing the sustainable development of companies. Two key elements were highlighted in the model proposal: SCA and TCA management, as well as their correlations (Figure 4).

It can be assumed that it is crucial to implement a sustainable development strategy to maintain a SCA. The sustainable development strategy allows for a balanced response to changes in the natural environment and the preservation of foundations that provide a sustainable development (as mentioned in RBV). 


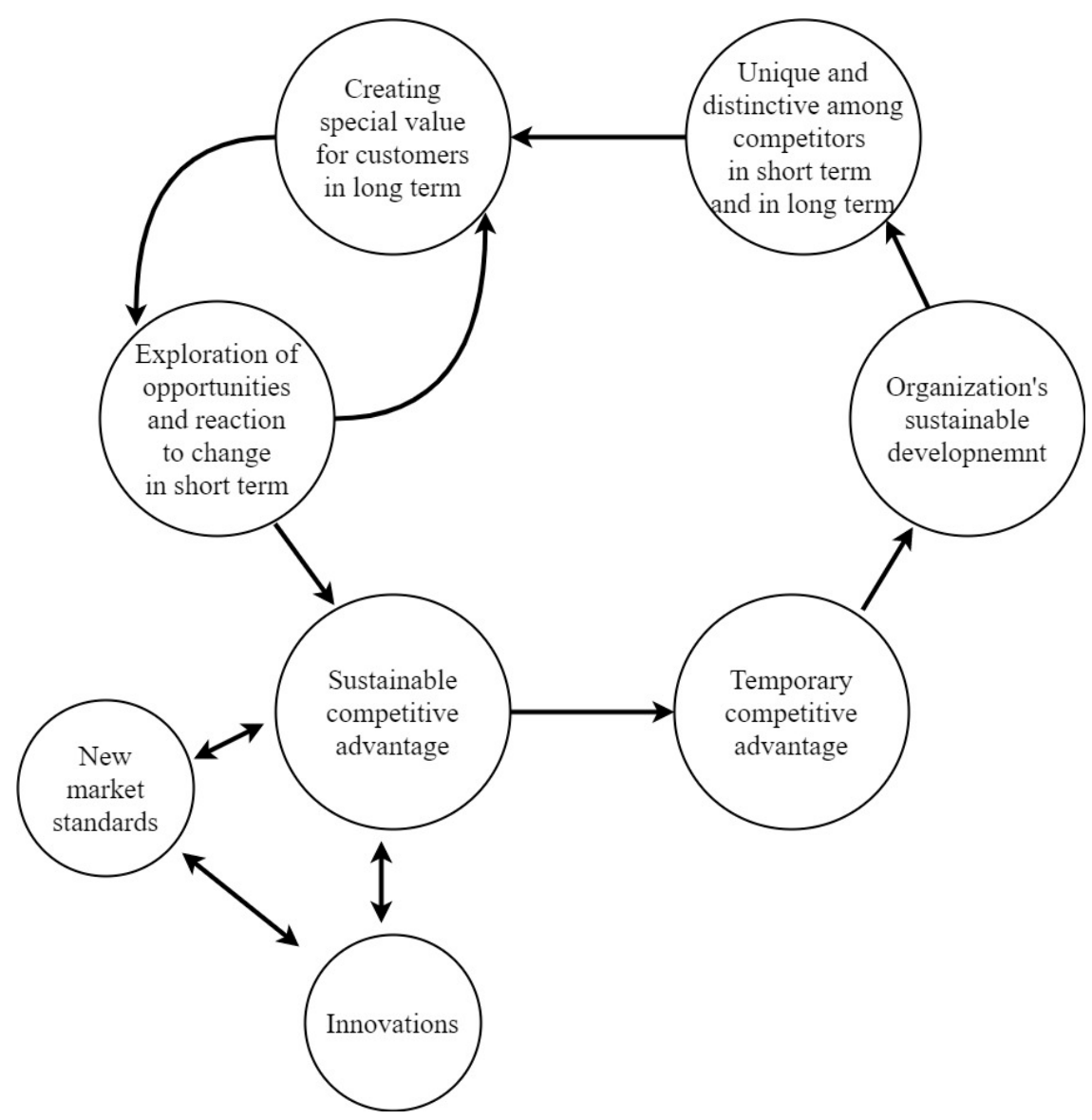

Figure 4. Model of gaining a SCA and a TCA in the unstable business environment. Source: Authors' elaboration.

Presented in Figure 4 is the model of gaining a competitive advantage using the proposed model based on calculations (Figure 3). Therefore, literature studies and our research results confirm that it is possible to combine a SCA with a TCA. We stress that the competitive advantage is treated oppositely in different research proposals: as a fixed or variable element in the organization. This is also partially confirmed by the proposed model. The necessity to choose between action models aimed at changes or stability is difficult in the long run. The discussion on the shape of the competitive advantage is reasoned. Taking such an approach allowed us to propose a competitive advantage model combining dynamic (TCA) and fixed aspects (SCA). Such synergy should enable organizations to build a competitive advantage combining the features of a sustainable and temporary advantage. As a result, organizations can create a competitive advantage in an unstable business environment. Based on this study, we identified conditions for improving competitive advantage. These are:

1. Adoption of a basic operating model that can be continually improved;

2. The choice of several durable, timeless principles and values essential to organizations and customers and a wide range of stakeholders;

3. Focus on the flexibility to adapt to change in the long perspective.

To build a SCA, it is crucial to assume that some elements and activities make the company stand out among competing companies. These pillars of strategic sustainability are stable but can be improved [6]. This requires defining the basic principles of operation and their consistent implementation. On the other hand, a fresh approach to new solutions and initiatives is necessary, but it should be cautious. As a result, organizations create opportunities to develop and compete in a changing environment in the long term. 
A company focused on building SCA, plans to develop based on strategy and optimal resource use, mainly intangible. The essence of competitive advantage linear equilibrium is between SCA and a TCA. Recognition, as a priority for the organization's sustainability and variability, allows it to operate in different situations. The processes in an organization are about a combination of sustainable values, standards, and principles that are important for the organization's development in the long term and for responding with flexibility to rapid changes in the environment. The ecological sustainability of policies and values is the basis for a unique combination of the organization's sustainability and temporality. A balanced competitive advantage provides the customer with more excellent value in being a better organization in the long and short term. It is an advantage that can give the organization above-average profits in the long run as well as longevity.

\section{Conclusions}

The idea of strategic management based on the environmental change as an opportunity remains valid [6]. However, changes are needed to help adapt this process to the organization's needs and the environment. New phenomena and trends present challenges for researchers that create implications for research in strategic management. It is interesting to seek clarification of emerging phenomena and identify solutions to organizations' new situations. Little is known about the implementation of the strategy in the long term in a turbulent environment.

When the foundations of an organization, which are sustainable principles and values, are preserved, the company can implement consistent progressive actions and maintain dynamism. It seems right that, in implementing strategic management, organizations should strike a balance between change, flexibility, and long-term development. This approach allows the organization to avoid reckless actions. Then, an organization is capable of achieving outstanding results in the long term. These measures can help gain a sustainable competitive advantage, which determines the company's sustainable development for a long time in a changing environment.

We understand the limitations of the presented research that may have influenced the results of the study. There could be a problem in the survey in providing declarative answers to research questions. Research in strategic management is linked to the problem of objective opinions of respondents' responses reflected in the state of the art of crucial business managers. The study involved executive directors, strategic directors, managing directors, or the board, understood as the chairman of the board and the board members. Therefore, it should be assumed that they know the company, have information resulting from their observations, and are able to access research and analyses. Research into the strategic management process entails difficulties due to limited possibilities to verify the study results. The lack of precise assessment measures and criteria raises objectivity for the respondent and the researcher. A limitation of the research results is the fact that they were conducted among Polish enterprises. The idea of strategic management was implemented in Polish organizations much later than in other highly developed countries. Therefore, it is difficult to compare the research results in strategic leadership with other countries. In general, strategic management research is fragmented. Scientists more often analyze the strategic management process in several companies (case studies) or a group of organizations. Comparative studies of this process in organizations from different countries combining statistical analysis are rare.

An exciting direction of some further research is comparing the approach to sustainable competitive advantage and temporary competitive advantage in different countries' sectors and companies. Analyses dedicated to the competitive advantage from various perspectives will allow managers to gain a tool for managing the SCA and TCA. In further studies of competitive advantage, it is worthwhile to pay attention to several problems. First, it is essential to continue research in the area of synergies between SCA and TCA. The analysis of similarities and differences between these advantages and their strategies have set the next direction for research. Such studies should make it possible to clarify these terms and to indicate the detailed conditions for shaping SCA and TCA. 
A critical analysis of the literature in strategic management indicates a gap in research on sustainable competitive advantage in terms of responsibility for society and the environment. So far, when examining the permanent competitive advantage (SCA), attention has been paid primarily to the duration of the advantage. Most of the researches on SCA ignore the aspects related to the protection of people and the environment. Organizations' challenges in the 21st century are marked by environmental destruction and disproportions in the quality of life between nations or social groups, and is not the popular subject of research in competitive advantage. It can be assumed that the idea of a SCA will gain importance again, as it may support organizations in solving the contemporary world's problems. We acknowledge that in a rapidly changing world, organizations should change. However, stabilization is also needed, a particular value offered to clients, stakeholders, and the environment in the long term.

This research contributes to the strategic management literature and entails some practical managerial implications. The model outlined in this paper is significant because it offers an opportunity to fill a void in understanding how organizations might successfully develop a SCA and TCA in an unstable business environment. Organizations with a SCA can be admired because they gain a stable development position, despite the volatile environment. They are exemplary because they can develop stability over the long-term operation, take care of the organization's values and the environment, and think about employees as a key resource of the company, which can contribute to success in the competitive struggle. Today, however, the competitive advantage of most companies does not last long. The search for a distinctive, hard-to-copy competitive advantage requires rejecting the belief that stability is the management norm. The need to set the direction of the organization's development is actual, but companies also need new rules for managing their competitive advantage. The starting point for building an advantage is understanding the importance of the role it plays in development. Companies that can maintain a competitive advantage give advantages to a permanent character. They offer customers a unique and challenging to-copy solution, and consolidate a company's image associated with a durable, attractive offer. Companies that can maintain a competitive advantage give advantages to a permanent character. A permanent competitive advantage (SCA) combined with a TCA allows the organization to build a competitive advantage in a changing environment. This advantage responds to changes in the environment and inside the organization. Another managerial implication is that creating an advantage does not only result from the company's ability to combine SCA and TCA. The synergy of competitive advantages allows the use of new opportunities and the development of the organizations' core business. This approach requires the formulation of basic assumptions to build the sustainability of the organization. By following these principles, organizations increase their chances of stable growth and in achieving excellent results in the short and long term. It can be assumed that having a SCA and TCA focused not only on economic values but also on social and environmental challenges, resulting from the implementation of sustainable strategic management.

The problems of the modern world, such as rising raw material prices and the limited number of resources, increase the need to implement sustainable development. This, in turn, requires taking into account social and environmental conditions in a competitive advantage. Businesses have the opportunity to become socially mature by engaging in responsible investments that build value for business and society. Companies can become mature organizations by engaging in responsible investments that create value for a business, society, and the natural environment.

Today, maintaining a competitive advantage requires initiating positive changes in a diverse world regarding social or economic development and environmental degradation. Customer knowledge about the importance of global development problems is just developing. It can be assumed that the competitiveness of organizations friendly to society and the natural environment, offering products that meet new customer expectations, will increase. This approach to the common good requires a long-term focus on profits as well as prioritizing global and local environmental and social problems. 
Author Contributions: Conceptualization, L.S.-P. and A.S.; methodology, L.S.-P and A.S.; software, A.S.; validation, A.S.; formal analysis, L.S.-P.; investigation, A.S and L. S-P.; resources L.S.-P. and A.S.; data curation, A.S.; writing-original draft preparation, L.S-P. and A.S.; writing-review and editing, L.S.-P. and A.S.; visualization, A.S.; supervision, L.S.-P. and A.S.; project administration, A.S.; funding acquisition L.S.-P. and A.S. All authors have read and agreed to the published version of the manuscript

Funding: (A.S.) The project is financed by the National Science Centre in Poland under the program "Business Ecosystem of the Environmental Goods and Services Sector in Poland" implemented in 2020-2022, project number 2019/33/N/HS4/02957, total funding amount 120 900.00 PLN. (L.S.-P.) The project is financed by the Ministry of Science and Higher Education in Poland under the program "Regional Initiative of Excellence" 2019-2022, project number 015/RID/2018/19, total funding amount 10721 040.00 PLN.

Conflicts of Interest: The authors declare no conflict of interest. The funders had no role in the design of the study; in the collection, analyses, or interpretation of data; in the writing of the manuscript, or in the decision to publish the results.

\section{References}

1. Beliaeva, T.; Ferasso, M.; Kraus, S.; Damke, E.J. Dynamics of digital entrepreneurship and the innovation ecosystem. Int. J. Entrep. Behav. Res. 2019, 26, 266-284. [CrossRef]

2. Prahalad, C.K.; Hamel, G. The Core Competence of the Corporation. Strateg. Unternehm. 2006, 69, $275-292$. [CrossRef]

3. Farias, G.; Farias, C.; Krysa, I.; Harmon, J. Sustainability Mindsets for Strategic Management: Lifting the Yoke of the Neo-Classical Economic Perspective. Sustainability 2020, 12, 6977. [CrossRef]

4. Eller, F.J.; Gielnik, M.M.; Wimmer, H.; Thölke, C.; Holzapfel, S.; Tegtmeier, S.; Halberstadt, J. Identifying business opportunities for sustainable development: Longitudinal and experimental evidence contributing to the field of sustainable entrepreneurship. Bus. Strat. Environ. 2020, 29, 1387-1403. [CrossRef]

5. Drnevich, P.L.; Mahoney, J.T.; Schendel, D. Has Strategic Management Research Lost Its Way? Strat. Manag. Rev. 2020, 1, 35-73. [CrossRef]

6. Sulich, A.; Zema, T. Green jobs, a new measure of public management and sustainable development. Eur. J. Environ. Sci. 2018, 8, 69-75. [CrossRef]

7. Hart, S.L.; Dowell, G. A natural-resource-based view of the firm: Fifteen years after. J. Manag. 2011, 37, 1464-1479.

8. Porter, M.; Siggelkow, N. Contextuality Within Activity Systems and Sustainability of Competitive Advantage. Acad. Manag. Perspect. 2008, 22, 34-56. [CrossRef]

9. Hummels, H.; Argyrou, A. Planetary demands: Redefining sustainable development and sustainable entrepreneurship. J. Clean. Prod. 2021, 278, 123804. [CrossRef]

10. Guimarães, J.; Severo, E.; Vasconcelos, C. Sustainable Competitive Advantage: A Survey of Companies in Southern Brazil. Braz. Bus. Rev. 2017, 14, 352-367. [CrossRef]

11. Wegner, D.; Ferasso, M.; Fracasso, E.M. Decisões financeiras na empresa biscoitos Santa Cruz. Revista de Administração Contemporânea 2009, 13, s1415-s65552009000300010. [CrossRef]

12. Sus, A.; Organa, M. Dynamics and the Dynamism of Strategy in Inter-organizational Network-Research Project Assumptions. In Advances in Analytics and Applications; Springer Science and Business Media LLC: Berlin, Germany, 2019; pp. 313-330.

13. Krupski, R.; Piórkowska, K.; Sus, A. Organizational endogenous development: The micro-foundations, opportunities and real options perspective. Argum. Oeconomica 2017, 1, 63-97. [CrossRef]

14. Barney, J.B. Looking inside for competitive advantage. Acad. Manag. Perspect. 1995, 9, 49-61. [CrossRef]

15. Yolles, M. Competitive advantage and its conceptual development. Bus. Inf. Rev. 2009, 26, 93-111. [CrossRef]

16. Stead, J.G.; Stead, W.E. The Coevolution of Sustainable Strategic Management in the Global Marketplace. Organ. Environ. 2013, 26, 162-183. [CrossRef]

17. Sulich, A.; Grudziński, A. The Analysis of Strategy Types of the Renewable Energy Sector. Acta Univ. Agric. et Silvic. Mendel. Brun. 2019, 67, 1643-1651. [CrossRef]

18. Suriyankietkaew, S.; Petison, P. A Retrospective and Foresight: Bibliometric Review of International Research on Strategic Management for Sustainability, 1991-2019. Sustainability 2019, 12, 91. [CrossRef]

19. Stańczyk-Hugiet, E. Path dependence destiny? Organizational routines and (dynamic) capabilities perspective. In Dynamic Capabilities and Their Strategic Dimension: Aspects of Imitation and Innovation; Krzakiewicz, K., Cyfert, S., Eds.; Uniwersytet Ekonomiczny w Poznaniu: Poznań, Poland, 2019; pp. 90-105. 
20. Huang, K.-F.; Dyerson, R.; Wu, L.-Y.; Harindranath, G. From Temporary Competitive Advantage to Sustainable Competitive Advantage. Br. J. Manag. 2015, 26, 617-636. [CrossRef]

21. O'Shaughnessy, N.J. Michael Porter's Competitive Advantage revisited. Manag. Decis. 1996, 34, 12-20. [CrossRef]

22. O'Shannassy, T. Sustainable competitive advantage or temporary competitive advantage. J. Strat. Manag. 2008, 1, 168-180. [CrossRef]

23. D'Aveni, R.A.; Dagnino, G.B.; Smith, K.G. The age of temporary advantage. Strat. Manag. J. 2010, 31, 1371-1385. [CrossRef]

24. Sirmon, D.G.; Hitt, M.A.; Arregle, J.-L.; Campbell, J.T. The dynamic interplay of capability strengths and weaknesses: Investigating the bases of temporary competitive advantage. Strat. Manag. J. 2010, 31, 1386-1409. [CrossRef]

25. Hinterhuber, A. Can competitive advantage be predicted? Manag. Decis. 2013, 51, 795-812. [CrossRef]

26. Ma, H. Anatomy of competitive advantage. Manag. Decis. 2018, 37, 709-718. [CrossRef]

27. Ireland, R.D.; Webb, J.W. Strategic entrepreneurship: Creating competitive advantage through streams of innovation. Bus. Horizons 2007, 50, 49-59. [CrossRef]

28. Bell, G. The end of the strategy world as we know it? Strat. Dir. 2013, 29, 37-40. [CrossRef]

29. Urbancova, H. Competitive Advantage Achievement through Innovation and Knowledge. J. Compet. 2013, 5, 82-96. [CrossRef]

30. Eisenhardt, K.M.; Martin, J.A. Dynamic capabilities: What are they? Strateg. Manag. J. 2000, 21, $1105-1121$. [CrossRef]

31. Porter, M.E. The Contributions of Industrial Organization to Strategic Management. Acad. Manag. Rev. 1981, 6, 609-620.

32. Barney, J.B.; Wright, P.M. On becoming a strategic partner: The role of human resources in gaining competitive advantage. Hum. Resour. Manag. 1998, 37, 31-46. [CrossRef]

33. Peteraf, M.A. The cornerstones of competitive advantage: A resource-based view. Strat. Manag. J. 1993, 14, 179-191. [CrossRef]

34. Grant, R.M. The Resource-Based Theory of Competitive Advantage: Implications for Strategy Formulation. Calif. Manag. Rev. 1991, 33, 114-135. [CrossRef]

35. Peteraf, M.A.; Barney, J.B. Unraveling the resource-based tangle. Manag. Decis. Econ. 2003, 24, 309-323. [CrossRef]

36. Jurksiene, L.; Pundziene, A. The relationship between dynamic capabilities and firm competitive advantage. Eur. Bus. Rev. 2016, 28, 431-448. [CrossRef]

37. Nayeemunnisa, A.; Gomathi, S. Influence of Organizational Capabilities on Innovative Climate and Talent Retention. Int. J. Recent Technol. Eng. 2019, 8, 9788-9792.

38. Stonehouse, G.; Snowdon, B. Competitive Advantage Revisited: Michael Porter on Strategy and Competitiveness. J. Manag. Inq. 2007, 16, 256-273. [CrossRef]

39. Elliott, J.E. Marx and Schumpeter on Capitalism's Creative Destruction: A Comparative Restatement. Q. J. Econ. 1980, 95, 45. [CrossRef]

40. Barney, J.B. Is the Resource-Based “View” a Useful Perspective for Strategic Management Research? Yes. Acad. Manag. Rev. 2001, 26, 41-56. [CrossRef]

41. Kang, S.; Na, Y.K. Effects of Strategy Characteristics for Sustainable Competitive Advantage in Sharing Economy Businesses on Creating Shared Value and Performance. Sustainability 2020, 12, 1397. [CrossRef]

42. Rumelt, R.P. How much does industry matter? Strateg. Manag. J. 1991, 12, 167-185. [CrossRef]

43. Crook, T.R.; Ketchen, D.J.; Combs, J.G.; Todd, S.Y. Strategic resources and performance: A meta-analysis. Strat. Manag. J. 2008, 29, 1141-1154. [CrossRef]

44. Black, J.A.; Boal, K.B. Strategic resources: Traits, configurations and paths to sustainable competitive advantage. Strat. Manag. J. 2007, 15, 131-148. [CrossRef]

45. Sanusi, A.; Sumiyati, L.; Winata, A.; Hakim, L. Developing a model of sustainable competitive advantage. Int. J. Innov. Creat. Chang. 2020, 12, 34-43.

46. Teece, D.J.; Pisano, G.; Shuen, A. Dynamic capabilities and strategic management. Strateg. Manag. J. 1997, 18, 509-533. [CrossRef]

47. Barreto, I. Dynamic Capabilities: A Review of Past Research and an Agenda for the Future. J. Manag. 2009, 36, 256-280. [CrossRef] 
48. Dagnino, G.B.; Picone, P.M.; Ferrigno, G. Temporary Competitive Advantage: An Investigation into the Core of the Literature. Acad. Manag. Proc. 2016, 2016, 17087. [CrossRef]

49. Hitt, M.A.; Keats, B.W.; Demarie, S.M. Navigating in the new competitive landscape: Building strategic flexibility and competitive advantage in the 21st century. Acad. Manag. Perspect. 1998, 12, 22-42. [CrossRef]

50. Merrifield, D.B. Changing Nature of Competitive Advantage. Res. Manag. 2000, 43, 41-45. [CrossRef]

51. Lengnick-Hall, C.A. Innovation and Competitive Advantage: What We Know and What We Need to Learn. J. Manag. 1992, 18, 399-429. [CrossRef]

52. McGrath, R.G. The End of Competitive Advantage: How To Keep Your Strategy Moving as Fast as Your Business. 2013. Available online: https://www.strategy-business.com/article/00239?gko=8e 54d (accessed on 21 October 2020).

53. Elahi, E. Risk management: The next source of competitive advantage. Foresight 2013, 15, 117-131. [CrossRef]

54. Fiegenbaum, A.; Thomas, H. Strategie risk and competitive advantage: An integrative perspective. Eur. Manag. Rev. 2004, 1, 84-95. [CrossRef]

55. Stieglitz, N.; Becker, M.C.; Knudsen, T. Strategic Focus and the Quest for Temporary Advantage. Acad. Manag. Proc. 2009, 2009, 1-6. [CrossRef]

56. Wiggins, R.R.; Ruefli, T.W. Schumpeter's ghost: Is hypercompetition making the best of times shorter? Strateg. Manag. J. 2005, 26, 887-911. [CrossRef]

57. Wiggins, R.R.; Ruefli, T.W. Sustained Competitive Advantage: Temporal Dynamics and the Incidence and Persistence of Superior Economic Performance. Organ. Sci. 2002, 13, 81-105. [CrossRef]

58. Helfat, C.E.; Peteraf, M.A. The dynamic resource-based view: Capability lifecycles. Strateg. Manag. J. 2003, 24, 997-1010. [CrossRef]

59. Hafeez, K.; Zhang, Y.; Malak, N. Core competence for sustainable competitive advantage: A structured methodology for identifying core competence. IEEE Trans. Eng. Manag. 2002, 49, 28-35. [CrossRef]

60. McGrath, R.G. Sustainable competitive advantage and the management of technology and innovation. In Proceedings of the 2004 IEEE International Engineering Management Conference (IEEE Cat No 04CH37574) IEMC-04, Singapore, 18-21 October 2004. [CrossRef]

61. Newbert, S.L. Value, rareness, competitive advantage, and performance: A conceptual-level empirical investigation of the resource-based view of the firm. Strat. Manag. J. 2008, 29, 745-768. [CrossRef]

62. González-Rodríguez, M.R.; Díaz-Fernández, M.C. Customers' corporate social responsibility awareness as antecedent of repeat behaviour intention. Corp. Soc. Responsib. Environ. Manag. 2020, 27, 1294-1306. [CrossRef]

63. Hoffman, N.P. An Examination of the Sustainable Competitive Advantage Concept: Past, Present, and Future. Acad. Mark. Sci. Rev. 2000, 4, 1-16.

64. Franchetti, M.J.; Elahi, B.; Ghose, S. Green Supply Chain, Logistics and Transportation. Green Lean Manag. 2017, 1-16. [CrossRef]

65. Wang, C.L.; Ahmed, P.K. Dynamic capabilities: A review and research agenda. Int. J. Manag. Rev. 2007, 9, 31-51. [CrossRef]

66. Lin, C.; Tsai, H.-L. Achieving a firm's competitive advantage through dynamic capability. Balt. J. Manag. 2016, 11, 260-285. [CrossRef]

67. Madsen, T.L.; Leiblein, M.J. What Factors Affect the Persistence of an Innovation Advantage? J. Manag. Stud. 2015, 52, 1097-1127. [CrossRef]

Publisher's Note: MDPI stays neutral with regard to jurisdictional claims in published maps and institutional affiliations.

(C) 2020 by the authors. Licensee MDPI, Basel, Switzerland. This article is an open access article distributed under the terms and conditions of the Creative Commons Attribution (CC BY) license (http://creativecommons.org/licenses/by/4.0/). 